\title{
Capital Structure and Profitability of Downstream Oil and Gas Firms Listed in Nigeria
}

\author{
Alalade, Yimka S. (Ph.D) Ogbebor, Peter I. (Ph.D)* Nyaudo, Theodore (M.Sc Student). \\ Department of Finance, School of Management Sciences, Babcock University, \\ Ilishan-Remo, Ogun State Nigeria
}

\begin{abstract}
The Nigerian downstream oil and gas sector in the last few years have witnessed a plethora of challenges such as infrastructural decay, rising cost of importation of petroleum products (fuel, diesel, aviation fuel and kerosene) which is a fallout of breakdown of the nation's refineries. The study examined the impact of capital structure on the profitability of firms in the downstream sector of the oil and gas industry in Nigeria from 2000 to 2018 . This study adopted an ex-post facto research design. The study employed a dynamic panel system equation of generalized method of moment. Secondary data were sourced from the annual reports of the 8 selected oil and gas companies listed in Nigeria. The study applied descriptive statistics, correlation, and unit root test as well as inferential statistics. Inferences were made at 5 percent significant level. Results showed that Debt Capital ratio had a negative and significant relationship with $\operatorname{ROA}(\beta=-0.0257, \mathrm{t}=-5.147, p<0.05)$. Also, Equity Capital ratio had a positive and significant relationship with current $\operatorname{ROA}(\beta=0.228, \mathrm{t}=5.3015 p<0.05)$. Lastly, Interest Rate had a positive and insignificant relationship with current $\operatorname{ROA}(\beta=0.247, \mathrm{t}=4.3521, p<0.05)$. The study concluded that while debt capital ratio had a significant inverse effect on firms' profitability, equity capital ratio had a positive and significant effect on the profitability of the selected oil and gas firms. The result also affirmed that interest rate had a positive and insignificant effect on profitability of selected oil and gas firms. The study recommended that Oil and Gas sector should increase equity financing and reduce debt financing. This equity can be enhanced through increased in the amount of ploughed back profit/retained earnings and bonus issue.
\end{abstract}

Word counts: 281

Keywords: Capital Structure, Profitability, Equity capital ratio, Debt Capital ratio

DOI: $10.7176 /$ RJFA/11-8-02

Publication date: April $30^{\text {th }} 2020$

\section{Introduction}

Capital is an important and critical resource for all companies. Capital structure of a corporate firm usually comprises equity and debt components. Equity is the component of a firm's capital that provides funds to the firm through the sale of some part-ownership rights to investors. The firm employs the funds so raised for the purposes of its operations and investment activities. On the other hand, debt as a component of firm's capital structure is a contractual agreement, whereby a firm or company borrows an amount of money, pays agreed interests on the borrowed sum, and ultimately repays the borrowed amount of money on maturity or at a stipulated time. The firm employs part of the debt amount to finance its assets. The amount of debt that a firm uses to finance its assets is called leverage. A firm with a lot of debt in its capital structure is said to be highly leveraged. A firm with no debt is said to be unleveraged. There is a wide range of policy issues involving how companies finance their activities. Capital market development, interest rate, security price determination and regulation are examples of macro-level implications while corporate governance and company development constitute micro-level implications (Green, 2004).

Appropriate and optimum utilization policy is necessary in sourcing for finance. In pursuing the wealth maximization objective of a firm, finance managers are expected to adopt commensurate financing options so as to ensure maximization of returns to owners of the business without compromising the interests of other stakeholders. Therefore, capital structure is a financing option or totality of sources of funds available to such businesses which involve a mix of both equity and debt capital in the financing of assets and operations of the firms. Available literature suggests that the well-orchestrated 'optimal capital structure' as postulated by the traditional school of thought has been very difficult to achieve by most firms. A firm attains an optimum capital structure when its weighted average cost of capital is at lowest. Capital Structure came into lime light with Modigliani and Miller (1958) opposing the postulation. The theorem by Modigliani-Miller (MM) considers capital structure theories to function under certain assumption which includes perfect market conditions, a world of no taxation, rationality of investors, absence of bankruptcy costs and efficient capital market. Thus, the MM Theory opposed the traditional school of thought by contesting the argument that there is optional capital structure. To them, the value of the firm depends on its expected performance and commercial risk, but not the way the firm is financed.

The relationship between capital structure and firm performance has attracted controversy in the literature of finance with financial economists examining its relevance to corporate organizations whether they are financial or 
non-financial firms. As it is well known, that global economy is witnessing trans-border movement of funds for investment purposes due to greater financial markets integration, especially in recent decades. With the Nigerian economy now interconnected with the global economy as a result of its openness to the outside world; this in turn has led to expansion in the operations and activities of Nigerian firms. Therefore, firms obtain funds from internal and external sources to finance their operations and business expansion. It should be noted that there are multiple financing sources, where the firms can depend on to finance their operations and new investments.

Sources of finance are categorized into two broad sources: -the internal financing which includes common stock issuance, preferred stocks, reserves and retained earnings. Another source, called external financing, is divided into short- and long-term loans and bonds issuance. As such, firms must choose the best financing sources to reach the optimal capital structure to be in harmony with firms' requirements to take suitable financing decisions and then reflect positively on performance.

The Nigerian downstream oil and gas sector in the last few years have witnessed a plethora of challenges such as infrastructural decay, rising cost of importation of petroleum products which is a fall out of breakdown of the country's refineries. The downstream oil and gas sector has been confronted with the issue of non-deregulation and liberalization of the sector, a situation where government fixes the prices of petroleum products instead of allowing the forces of demand and supply to determine prices resulting in dwindling profit margins of the downstream oil and gas companies. The subsector is also witnessing liquidity challenges due to non-payment of fuel subsidy by federal government amounting to billions of Naira in fuel subsidy arrears. The implication is that the probability of making profit in the downstream oil and gas sector is on the decline as a major portion of the profit is affected by interests' charges on loans and other incidental charges. The banking industry in recent times has witnessed a higher degree of nonperforming loans due to credit risks emanating from obligor defaults majorly attributable to the downstream oil and gas subsector; this is a fall out of dwindling revenue, liquidity and profitability in the subsector. There is a high degree of labour turnover, restructuring and realignment, mergers and/or takeovers of downstream oil and gas firms. Nigerian government ability to increase revenue generation has nose-dived and the country now resorts to external and local loans to fund her budget. (CBN, 2015). The decline in profit margins of downstream oil and gas companies and the ever-increasing costs of importation and operations of such companies in recent time are the main reason for this study.. The main question is why are the downstream oil and gas companies not as profitable as they should be considering the fact that the oil and gas sector is naturally a lucrative industry? Can the problem be attributable to their sources of finance? This study seeks to determine how capital structure has affected the profitability of companies in the downstream oil and gas sector in Nigeria, hence, the main objective of this study is to examine the impact of capital structure on the profitability of firms in the downstream oil and gas companies listed in Nigeria.

\section{Literature Review}

\subsection{Capital Structure}

In the words of Pandey (2010), capital structure is a financial plan that refers to the composition of long term sources of funds such as debentures, long term debts, preference and ordinary share capital including reserves and surplus, while Yegon (2014) defined capital structure as how a firm finances its overall operations and growth by using different sources of funds. Debt comes in the form of bond issues or long-term notes payable, while equity is classified as common stock, preferred stock or retained earnings. Again, capital structure is frequently used to indicate the long-term sources of funds employed in a business enterprise.

Furthermore, capital structure of a firm is the mix of debt, equity and other sources of finance that management of a firm uses to finance the firm's activities. Different firms use different proportion or mix of longterm funds. A firm may decide to use all equity or all debt. Greater proportion of debt is preferred by investors in a country where debt interest is tax deductible. Firms use a mix of debt and equity in various proportions in order to maximize the overall market value of the firm (Rahman, Sarker \& Uddin, 2019).

\subsection{Theoretical framework}

\subsubsection{Modigliani and Miller Proposition without Tax}

This theory was put forward by Modigliani and Miller (MM) in 1958 with the underlying assumptions of a world with no transactions cost, no taxation, no bankruptcy cost, and no effect of debt on earnings before interest and tax. The theory indicates that in a perfect market, it does not matter the capital structure mix used by the firm since the value of the firm remains constant. Furthermore, the authors postulated that under these conditions, the type of capital used in financing the business is irrelevant, thus, there is nothing like optimal debt to equity ratio. This stream of research tried to identify the depth of the relationship between leverage and market value of companies and marks the starting point of modern theory of capital structure. Modigliani and Miller (1958) theorized that in perfect capital markets, changes in the capital structure of a firm do not affect its market value and subsequently has no effect on financial performance. Akinselure (2017) noted that the theory created a fictional world without taxes, transaction costs, bankruptcy costs, growth opportunities, asymmetric information between insider and 
outsider investors and differences in risks between different firms and individuals. This world is a mere fiction and not expedient in practice.

\subsubsection{Irrelevant and Relevant Theory}

Modigliani and Miller (1958) postulated that under certain key assumptions, firm's value is unaffected by its capital structure and that what is important is the earning capacity of assets as the method of financing a business has nothing to do with the value of the business. A fundamental assumption of the Modigliani and Miller [(M-M), (1958)] theory is that capital markets are assumed to be perfect where insiders and outsiders have free access to information, a world of no transaction cost, no bankruptcy cost and no taxation, among others, hence, the choice between equity and debt becomes irrelevant and internal and external funds can be perfectly substituted. The main argument in the M-M theory is that the value of a firm should not depend on its capital structure but the capacity of its assets. The theory argued further that a firm should have the same market value and the same weighted average cost of capital (WACC) at all capital structure levels because the value of a company should depend on the return and risks of its operation and not on the way it finances its operations. Miller brought forward the next version of irrelevance theory of capital structure and appealed that capital structure decision of firms with both corporate and personal taxes circumstances are irrelevant (Yisau, 2016).

\subsubsection{Agency Cost Theory}

This is a theory concerning the relationship between the principal (shareholders) and the agent of the principal (company's managers). This suggests that the firm can be viewed as a nexus of contracts (loosely defined) between resource holders. An agency relationship arises whenever one or more individuals, called principals, hire one or more other individuals, called agents, to perform some service and then delegate decision- making authority to the agents. The agency theory concept is based on the argument that due to a continuous dilution of equity ownership of large corporations, ownership and control become more separated. This situation gives professional managers an opportunity to pursue their own narrow interests instead of shareholders' interests. This therefore creates friction and the whole essence of delegation of responsibility is defeated as shareholders' wealth cannot be maximized in such circumstances. This has justified the use of debt and in increased proportion even without the obvious tax advantages it confers on returns to shareholders. Illustratively, Pratomo and Ismail (2006) suggested an optimal debt level in capital structure through minimizing the agency costs arising from the divergent interests of managers with shareholders and debt holders. The authors suggested that either ownership stake of managers in the firm should be increased in order to align the interest of managers with those of the owners or the use of debt should be increased in order to control managers' tendency for excessive extra consumptions. The authors suggested that free cash flow problem can be controlled by increasing the stake of managers in the business or by increasing debt in the capital structure, thereby reducing the amount of "free" cash available to managers. This therefore is an indication that firms which are mostly financed by debt give managers less power than those financed mostly by equity, thus, debt can be used as a control mechanism, in which lenders and shareholders become the principal parties in the corporate governance structure.

\subsection{Empirical Review}

Akinlo and Taiwo (2012) studied the empirical analysis of capital structure on Firms' Performance in Nigeria using Panel Least Square regression model. The result of the research supported the agency cost hypothesis which showed the existence of a negative relationship between return on asset and debt ratio. The result further indicated a negative relationship between return on equity and debt ratio and a positive relationship between return on asset and asset turnover while an inverse relationship was found between return on asset and asset tangibility. The authors further established that return on asset and firm size was positive but not significant, while the relationship between return on equity and asset turnover, firm size and age was positive and significant. Hence, the author recommended that asset tangibility should be a driving factor to capital structure because firms with more tangible assets are less likely to be financially constrained. Appah (2013) examined the effect of capital structure on the operating performance of quoted firms on the Nigeria Stock Exchange using panel and cross sectional time series technique in the review of 224 financial reports of quoted companies between the period 2005 and 2011. The result revealed that short term debt, long term debt and total debt have significant and negative relationship with performance using return on asset, return on equity and tangibility and efficiency as a proxy for performance while non-tax debt and liquidity showed a negative relationship with performance. On the basis of this result, the study concluded that capital structure affects the performance of firms. On their part, Edim, Atseye and Eke (2014) investigated the relationship between capital structure and firm performance, the findings of the study were in tandem with the traditional theory of capital structure which indicated that firms are likely to borrow more when profit are high thereby taking advantage of tax shield. The author further emphasized that long term debts should be utilized in the financing of long-term projects while short term debts should be employed in financing fast maturing financial obligation. The study concluded that financial managers should choose policies that increase stock holders' wealth. This finding, therefore, support the view that judicious use of debt and equity will enhance the financial performance and the value of the firm. (Nwankwo, 2014) explored the effect of capital structure of 
Nigerian firms on economic growth and the study adopted ordinary least square technique (OLS) and data were obtained from the Central Bank of Nigeria (CBN) and Nigeria Stock Exchange (NSE) from 1987 to 2012. The result of the findings indicated that capital structure of firms in Nigeria has a long run relationship with the growth and development of Nigerian economy. The implication of this finding is that capital structure of a firm will help to increase the growth of the economy in the long run if well managed. The study recommended that Nigerian firms should try and match their capital structure with real activities that will help to increase the level of economic growth in Nigeria; and that the firms should go for long term financing instead of going for short term loans or debt which formed most of their leverage; firms should focus on developing internal strategies that will help the economy to grow.

\section{Research Methodology}

The study employed quantitative method of data analysis with the aid of STATA 15 statistical package. Specifically, the study employed descriptive analysis, unit root tests and consideration test as part of preliminary analysis. The descriptive analysis involved the use of mean, maximum, minimum and standard deviation to describe and summarize the variables of interest in this study. Further analysis which is inferential analysis employed in this study is the Arellano and Bond (1991) Generalized Method of Moments (GMM) estimator and the Blundell and Bond (1998) system GMM estimator to alleviate some econometric problems inherent in the use of pooled Ordinary Least Square (OLS), Fixed Effects (FE) and Random Effects (RE). GMM has been described as the most appropriate and efficient contemporary approach to address the prevailing econometric concerns (Arellano and Bond, 1991; Bond, 2002; Roodman, 2006; Yartey, 2008; Revia, 2014). Unlike the Fixed and Random panel regression approach, GMM is a dynamic estimator successfully correcting heteroscedasticity, serial correlation and endogenity bias that can lead to inconsistent estimates and incorrect inferences which is capable of providing misleading conclusions and inappropriate theoretical interpretations.

The Australian Bureau of Statistics (2016) defines Population as any complete group with at least one characteristic in common from which a statistical sample is drawn. The information obtained from the sample allows statisticians to develop hypothesis about the larger population. Kamau (2011) describes population as all the elements that meet the criteria for inclusion in a study. He describes criteria as a list of characteristics that are required for the membership in the targeted population. Sample of a study is a subset of the study population. That is, sample size is a part of the population of study interest.

The twelve (12) firms in the downstream sub-sector of the Nigerian oil and gas industry listed on the Nigerian Stock Exchange constitute the population of this study while purposive sampling technique was used to select the sample size of eight (8) firms.

\section{Model Specification}

The model below will be used for the empirical analysis and investigation of the relationship between the variables; it captures all the variables in the panel data. This is in line with Salawu and Awolowo, (2009). Olokoyo (2012) and Appah (2013). The data sets for the analysis span over time periods $(2000-2016)$ and across units (eight firms) in the oil and gas industry of the Nigerian economy. Therefore, the data sets have a combination of either time series or longitudinal and cross-sectional or latitudinal dimensions. The combination of time series with crosssection enhances the quality and quantity of data in ways that would be impossible using one of the two dimensions (Gujarati, 2003). Panel data design analysis provides a rich and powerful study of a set of attributes when considering both the space and time dimension of a given data sets Yaffee (2003). Though panel data are usually gathered on micro units like individuals, households and firms, biases resulting from aggregation of firms or individuals are eliminated. Blending the inter-individual differences and intra-individual dynamics fosters the advantage of panel data over time-series or cross-section data sets (Hsiao, 2003; 2007)

Considering profitability (PROFT) as the vector of the dependent variable, and components of capital structure (DEBTCAP and EQUITCAP) as well as interest rate (INTR) as matrix of the independent variables, with interest rate (INTR) entering the model as a moderating variable, the relationship is functionally expressed as shown below in a dynamic form.

PROFT $_{\text {it }}=\mathrm{f}\left(\right.$ DEBTCAP $_{\text {it }}$, EQUITCAP $_{\text {it }}$, INTR $\left._{\text {it }}\right)$

Where

PROFTi $_{\mathrm{t}}=$ Profitability (measured as Return on Asset) for entity $i$ time period $\mathrm{t}$.

DEBTCAP $_{i t}=$ Debt capital for entity $i$ time period $t$.

EQUITCAP $_{i t}=$ Equity capital forentity $i$ time period $\mathrm{t}$.

$\mathrm{INTR}_{i t}=$ Interest rate (average) in time period $\mathrm{t}$.

\section{Analytical Model}

The functional relationship above translates to the following aggregative dynamic analytical model: $\mathrm{ROA}_{\mathrm{it}}=\alpha_{0}+\beta_{1} \mathrm{ROA}_{\mathrm{it}-1}+\beta_{2} \mathrm{DEBTCAP}_{\mathrm{it}}+\varepsilon_{\mathrm{it}}$ 
$\mathrm{ROA}_{\mathrm{it}}=\alpha_{0}+\beta_{1} \mathrm{ROA}_{\mathrm{it}-1}+\beta_{2} \mathrm{EQUITCAP}_{\mathrm{it}}+\varepsilon_{\mathrm{it}}$

$\mathrm{ROA}_{\mathrm{it}}=\alpha_{0}+\beta_{1} \mathrm{ROA}_{\mathrm{it}-1}+\beta_{2} \mathrm{INTR}_{\mathrm{it}}+\varepsilon_{\mathrm{it}}$

Where

$\mathrm{ROA}_{\mathrm{it}}=$ Return on Asset forentity itime period t.

$\mathrm{ROA}_{\mathrm{it}-1}=$ Return on Asset forentity itime period t-1.

DEBTCAP $_{i t}=$ Debt capital forentity $i$ time period $\mathrm{t}$.

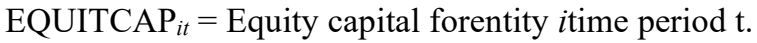

$\mathrm{INTR}_{i t}=$ Interest rate (average) in time period t..

$\varepsilon_{\mathrm{it}}=$ Random variables that render the model stochastic over the time, $t$. That is, it accommodates latent influences of other variables that may affect the profitability of the firms but which are not explicitly included in the model. $t=$ identifier for the respective years relevant to the study. $1,2,3, \ldots, 19$ years.

The identifier, $t-1$, renders the model dynamic from the preceding time period $(t-1)$ to the succeeding time period $(t)$ during the $t=1,2,3, \ldots, 19$ years.

\section{Data analysis and discussion of findings \\ 4.1 Descriptive Statistics}

The study used panel data for the period ranging from 2000 - 2018. It should be noted that the panel data is a balanced panel because all the selected firms have data for the period. Table 4.1 showed the numbers of observations, mean, median, maximum, minimum and standard deviations of each of the dependent and independent or explanatory variables. In this study, we used two categories of variables which are discussed in this section. The first category is the dependent variable and it is Return on Asset (ROA). It is defined as the ratio of net income (Profit after Tax) to Total Assets. The second category are the explanatory variables and they are: Debt capital (DEBTCAP), Equity capital (EQUITCAP) and Interest rate (INTR).

\section{Table 4.1: Descriptive Statistics}

\begin{tabular}{lccccc}
\hline Variable & Obs & Mean & Std. Dev. & Min & Max \\
\hline ROA & 171 & -0.009 & 0.267 & -2.792 & 0.246 \\
DEBTCAP & 171 & 0.823 & 0.654 & 0.105 & 7.474 \\
EQUITCAP & 171 & 0.188 & 0.651 & -6.474 & 0.895 \\
INTR & 171 & 17.851 & 2.051 & 15.135 & 24.850
\end{tabular}

Source: Authors' computations, 2020

Return on Asset (ROA): The mean value of Return on Asset (ROA) is -0.009 when the number of observations is 171 . The standard deviation which is a measure of volatility or the degree of change is given as 0.267 , which suggests that there exists no such wide variation of the Return on Asset (ROA) of the companies concerned. The maximum and minimum values are 0.246 and -2.792 respectively, thus, percentage of profit being made by the companies in respect of overall assets is extremely low; due to narrow range in maximum and minimum values.

Debt capital (DEBTCAP): With the observation number being 171, the average value of the Debt capital (DEBTCAP) is 0.823 , which suggests that $82.3 \%$ of the total asset employed was financed by debt, which implies that the companies financed more than three-quarter of their assets with debt. Furthermore, the measure of the degree of volatility is given as 0.654 which signifies a rising trend in variation in the Debt capital (DEBTCAP) of the companies. The lowest and the highest values of the Debt capital (DEBTCAP) are 0.105 and 7.474, which supports the earlier made statement.

Equity capital (EQUITCAP): The mean value of the capital gotten by the companies upon selling shares [equity capital (EQUITCAP)] is 0.188 under the observation number 171 ; which means $18.8 \%$ equity capital was used, although, with wide range of variation in it, because the standard deviation is 0.651: this fact is buttressed by having the maximum and minimum values of the Debt capital (DEBTCAP) as 0.895 and -6.474 respectively.

Interest rate (INTR): The average value of percentage of the principal charged by the lender for the use of its money 'Interest rate (INTR)' for the companies, has been recorded is $17.851 \%$. With standard deviation being 2.051 , this implies that there exists a wide variation in the values of the Interest rate (INTR), with maximum and minimum values being 24.850 and 15.135 respectively and the observation number remains 171 .

\section{Panel Stationarity Test Result}

Im-Pesaran-Shin unit-root test was employed to study the time series features of the variables under consideration. The major strength of the IPS test is that it conducts test for each time series individually and then averages these tests to produce an overall test. The results are shown in Table 4.2. 
Table 4.2: Panel Stationarity Test Result

\begin{tabular}{|l|c|c|c|c|c|}
\hline \multirow{2}{*}{ Variable } & \multicolumn{2}{|c|}{ Level } & \multicolumn{2}{c|}{$@ \mathbf{1}^{\text {st }}$ Difference } & \multirow{2}{*}{ Order of Int. } \\
\cline { 2 - 6 } & Stat & P-value & Stat & P-value & \\
\hline ROA & 0.1648 & 0.5654 & -5.6043 & 0.000 & $\mathrm{I}(1)$ \\
\hline DEBTCAP & -2.4857 & 0.1709 & -6.0185 & 0.000 & $\mathrm{I}(1)$ \\
\hline EQUITCAP & -1.9771 & 0.2034 & -5.5978 & 0.000 & $\mathrm{I}(1)$ \\
\hline INTRC & -2.0058 & 0.0677 & -5.4322 & 0.000 & $\mathrm{I}(1)$ \\
\hline
\end{tabular}

\section{Source: Authors' computation, 2020}

The result of the unit root test is presented in Table 4.2. The results showed that at $5 \%$ significance levels; Return on Asset (ROA), Debt capital (DEBTCAP), Equity capital (EQUITCAP) and Interest rate (INTR) are all stationary at first difference, implying that the variables are integrated of order one (I(1)).

\section{Panel Cointegration}

Given the I (1) properties of the series under consideration, the study proceeds to check whether a long-run relationship exists among these variables using the panel Cointegration approach proposed by Pederoni (2004). One of the advantages of the panel Cointegration approach is that it allows for multiple explanatory variables. Other advantages are that the approach allows for heterogeneity in the errors across the cross-sectional units and for the cointegrating vectors to vary across the sections of the panel. The result is presented in Table 4.3.

Table 4.3: Panel Cointegration Test Result.

\begin{tabular}{|c|c|c|}
\hline Test & Stat & P-value \\
\hline Modified Phillips-perron $t$ & 0.2661 & -1.553 \\
\hline Phillips-perron $t$ & -8.8426 & 0.0000 \\
\hline Augmented Dickey-Fuller $t$ & -4.7681 & 0.0000 \\
\hline
\end{tabular}

\section{Source: Authors' Computation, 2020}

Generally, the test shows evidence of cointegrating relationship among the variables given the fact that the Phillips-perron $t$ and Augmented Dickey-Fuller $t$ (Panel; parametric) produces more reliable evidence under Pedroni (1999) and two (2) out of the three (3) rejects the null hypothesis. Specifically, the Phillips-perron $t$ (p value $<0.05)$ and Augmented Dickey-Fuller $t(\mathrm{p}-$ value $<0.05)$ are significant at $5 \%$ of significance as shown in Table 4.3. These imply rejection of the null hypothesis of no - cointegration hence the study concludes that long run relationship exists among the variables.

\section{Regression Results}

This section presents and discusses the regression results based on the dynamic panel GMM noted earlier. It should be pointed out that the static model is fraught with a lot of weaknesses. First, the static model is faced with the possibility of mis-specification problem because of lack of specification test and conclusion drawn from the results will be biased. Second, static model is only able to address endogeneity issues arising from unobservable heterogeneity, but not simultaneity and dynamic endogeneity, and, therefore, potentially produces estimates that may be biased and inefficient leading to spurious results. To ameliorate the static model problem, the study employs the dynamic panel generalized method of moments (GMM) that accounts for both simultaneity and dynamic endogeneity. In other words, the study probes the dynamic relationship between impact of capital structure on profitability of firms in the downstream sector of the oil and gas industry in Nigeria using dynamic panel method that accounts for dynamics in the model. The dynamic panel in a generalized method of moment (GMM) framework follows approach developed by Arrllano and Bond (1991) and Blundell and Bond (1998) to obtain robust results. In addition, two (2) autocorrelations (AR(1) and AR(2)) tests and Hansen' tests among other diagnostics were conducted to confirm the validity of the GMM and validity of instruments used. The GMM is valid for estimation if the null hypothesis of $\operatorname{AR}(1)$ is rejected and the null hypothesis of either or both Sargan and Hansen' tests are accepted. 
Table 4.4: Return on Asset (ROA) and Debt Capital (DEBTCAP)

\begin{tabular}{|c|c|c|c|c|c|}
\hline VARIABLES & & $\frac{(1)}{\mathrm{SGMM}}$ & $\frac{(2)}{\mathrm{DGMM}}$ & $\frac{(3)}{\mathrm{SGMM}}$ & $\frac{(4)}{\mathrm{DGMM}}$ \\
\hline L.ROA & $\begin{array}{c}\text { Coef. } \\
\text { StdEr. } \\
\text { t-stat. } \\
\text { P - value }\end{array}$ & $\begin{array}{c}\mathbf{0 . 2 5 7 4} * * * \\
(0.0500) \\
5.1470 \\
(0.0009)\end{array}$ & $\begin{array}{c}\mathbf{0 . 1 9 1 1} \\
(0.1452) \\
1.3158 \\
(0.2247)\end{array}$ & $\begin{array}{c}\mathbf{0 . 2 4 6 7} * * * \\
(0.0567) \\
4.3521 \\
(0.0024)\end{array}$ & $\begin{array}{c}\mathbf{0 . 2 0 5 4} \\
(0.1414) \\
1.4528 \\
(0.1843)\end{array}$ \\
\hline DEBTCAP & $\begin{array}{c}\text { Coef. } \\
\text { StdEr. } \\
\text { t-stat. } \\
\text { P - value }\end{array}$ & $\begin{array}{c}\mathbf{- 0 . 0 2 5 7 * * *} \\
(0.0074) \\
-3.4654 \\
(0.0085)\end{array}$ & $\begin{array}{c}-\mathbf{- 0 . 0 7 0 5 *} \\
(0.0327) \\
-2.1579 \\
(0.0630)\end{array}$ & $\begin{array}{c}\mathbf{- 0 . 0 3 1 6 * * *} \\
(0.0037) \\
-8.6229 \\
(0.0000)\end{array}$ & $\begin{array}{c}\mathbf{- 0 . 0 6 0 3} \\
(0.0343) \\
-1.7567 \\
(0.1170)\end{array}$ \\
\hline INTR & $\begin{array}{c}\text { Coef. } \\
\text { StdEr. } \\
\text { t-stat. } \\
\text { P - value }\end{array}$ & & & $\begin{array}{c}0.8366 \\
(0.5259) \\
1.5909 \\
(0.1503)\end{array}$ & $\begin{array}{c}0.9729 \\
(0.6146) \\
1.5829 \\
(0.1521)\end{array}$ \\
\hline Constant & $\begin{array}{c}\text { Coef. } \\
\text { StdEr. } \\
\text { t-stat. } \\
\text { P - value }\end{array}$ & $\begin{array}{c}\mathbf{2 . 7 9 1 8} \\
(1.8059) \\
1.5459 \\
(0.1607)\end{array}$ & & $\begin{array}{c}-11.6652 \\
(9.9210) \\
-1.1758 \\
(0.2735)\end{array}$ & \\
\hline $\begin{array}{l}\text { Observations } \\
\text { F-statistic } \\
\text { Prob.(F-Stat.) } \\
\text { Hansen_test } \\
\text { Prob. (Hansen) } \\
\text { AR(1)_test } \\
\text { Prob. (AR(1)) } \\
\text { AR(2)_test } \\
\text { Prob. (AR(2)) } \\
\text { No. of Instruments }\end{array}$ & & $\begin{array}{c}\mathbf{1 6 2} \\
13.38 \\
0.003 \\
8.092 \\
0.965 \\
-2.357 * * \\
0.041 \\
0.725 \\
0.469 \\
3 \\
\end{array}$ & $\begin{array}{c}\mathbf{1 5 3} \\
97.04 \\
0.000 \\
2.591 \\
0.274 \\
-1.047 \\
0.295 \\
0.397 \\
0.691 \\
4 \\
\end{array}$ & $\begin{array}{c}\mathbf{1 6 2} \\
33.14 \\
0.000 \\
5.526 \\
0.996 \\
-1.984^{* *} \\
0.048 \\
0.614 \\
0.539 \\
3 \\
\end{array}$ & $\begin{array}{c}\mathbf{1 5 3} \\
91.91 \\
0.000 \\
3.020 \\
0.221 \\
-1.047 \\
0.295 \\
0.355 \\
0.723 \\
5 \\
\end{array}$ \\
\hline
\end{tabular}

Source: Authors' computations (2020)

Robust standard errors in parentheses

$* * * \mathrm{p}<0.01, * * \mathrm{p}<0.05, * \mathrm{p}<0.1$

The empirical representation of the estimated SGMM model is as shown below;

$\mathrm{ROA}_{\mathrm{it}}=\alpha_{0}+\beta_{1} \mathrm{ROA}_{\mathrm{it}-1}+\beta_{2} \mathrm{DEBTCAP}_{\mathrm{it}}+\varepsilon_{\mathrm{it}}$

$\mathrm{ROA}_{\text {it }}=\mathbf{2 . 7 9 1 8}+\mathbf{0 . 2 5 7 4} * \mathrm{ROA}_{\mathrm{it}-1} \mathbf{- 0 . 0 2 5 7} * \mathrm{DEBTCAP}_{\text {it }}+\varepsilon_{\text {it }}$

$\mathrm{ROA}_{\mathrm{it}}=\alpha_{0}+\beta_{1} \mathrm{ROA}_{\mathrm{it}-1}+\beta_{2}$ DEBTCAP $_{\mathrm{it}}+\beta_{3}$ INTR $_{\mathrm{it}}+\varepsilon_{\mathrm{it}}$

$\mathrm{ROA}_{\mathrm{it}}=-11.665+0.2467 * \mathrm{ROA}_{\mathrm{it}-1}-0.032 * \mathrm{DEBTCAP}_{\mathrm{it}}+0.837 * \mathrm{INTR}_{\mathrm{it}}+\varepsilon_{\mathrm{it}}$

Eqn .(1)

Eqn .(2)

\section{Serial correlation test and Over-identification restrictions}

Before interpreting the dynamic regression model, it is essential to verify the behaviour of the error term as well as the instruments used. As noted earlier in the preceding and this chapter, for a valid statistical inference from the estimated coefficients, the AR(1) test result which is Serial correlation must be significant while the AR(2) and Hanseny" tests results must be insignificant. The result in Table 4.4 shows that the AR(1) statistics for the models in columns (1) and (2) that regress Profitability indicator [Return on Asset (ROA)] on its lag and Debt Capital $($ DEBTCAP $)$ are given as $-2.357(\mathrm{P}-$ value $=0.041)$ and $-1.047(\mathrm{P}-$ value $=0.295)$ for the one-step system GMM (SGMM) and the one-step difference GMM (DGMM) respectively. Also, the result shows that the AR(1) statistics for the models in columns (3) and (4) that regress Profitability indicator (Return on Asset (ROA)) on its lag and Debt Capital (DEBTCAP) as well as Interest rate (INTR) are given as $-1.984(\mathrm{P}-$ value $=0.048)$ and $-1.047(\mathrm{P}-$ value $=0.295)$ for the one-step system GMM (SGMM) and one-step difference GMM (DGMM) respectively. These indicate that AR(1) one-step system GMMs in columns (1) and (3) are statistically significant at 5\% level as expected suggesting presence of serial correlation in the first order. However, it was revealed that there is absence of serial correlation in the second order of the SGMM model because the AR(2) statistic is given as 0.725 $(\mathrm{P}-$ value $=0.469)$ and $0.614(\mathrm{P}-$ value $=0.539)$ Another diagnostic test is the test for over-identifying restrictions. This test examines the lack of correlation between instruments and the error term. The result in Table 4.3 shows 
that the Hansen statistics of $8.092(\mathrm{P}-$ value $=0.965)$ and $5.526(\mathrm{P}-$ value $=0.996)$ for columns $(1)$ and $(3)$ respectively are not significant at the 5\% levels for the SGMM1 and SGMM2 models. This implies that the instruments used in the estimated models SGMMs are valid and generally, these mean that only the SGMMs diagnostics are satisfactory.

\section{Return on Asset (ROA) and Debt Capital (DEBTCAP)}

Interpreting the SGMM model, the results in column (1) of the Table 4.4 the F - statistic is 13.38 ( $\mathrm{p}-$ value $=$ 0.003 ) further suggested that the model is valid. In other words, debt capital (DEBCAP) and Return on Asset (ROA) at lag period 1 jointly explained changes in the current Return on Asset (ROA). Looking more closely at the results, past value of Return on Asset (ROA) exhibited positive and significant relationship with current value of ROA at $1 \%$ level of significance. Accordingly, the positive and significant relationship indicated that previous ROA is a significant factor of changes in current ROA. It also meant that a unit increase in past ROA causes current ROA to increase by 0.257 units. Additionally, the result showed that the current Debt Capital ratio has a negative and significant relationship with current ROA at $1 \%$ level. This is suggested that the DEBTCAP is a significant influence in the changes in ROA and that a unit increase in the DEBTCAP leads to about 0.026 units decrease in ROA of the selected oil and gas firms.

\section{Return on Asset (ROA) and Debt Capital (DEBTCAP) as well as Interest Rate (INTR)}

From the SGMM model's result in column (3) of the Table 4.4, we have a significant F- statistic $=33.14$; $p$ - value $=0.000)$ further suggested that the model is reliable. In other words, the combine effect of Debt Capital (DEBTCAP), Interest Rate (INTR) and Return on Asset (ROA) at lag period 1 on current Return on Asset (ROA) was statistically significant. Furthermore, the result showed that past value of Return on Asset (ROA) exhibited positive and significant relationship with current value of ROA at $1 \%$ level of significance and the positive and significant relationship indicated that previous ROA is a significant determinant of profitability indicator (ROA). It also means that current ROA increased by 0.247 units given a unit increase in past ROA. In addition, the result shows that the current Debt Capital ratio (DEBTCAP) has a negative and significant relationship with current ROA at $1 \%$ level. The negative impact becomes more significant after including the moderating variable (INTR). This suggested that the DEBTCAP is a significant factor of changes in ROA and Interest rate also influenced the effect of DEBTCAP on ROA of the selected oil and gas firms. As well, the result shows that the current Interest Rate has a positive and insignificant relationship with current ROA at 5\% level. This suggested that the INTR was not a significant determinant of ROA of the selected oil and gas firms during the period of this study.

Decisions: Following the result of the regression analysis in columns (1) and (3) of Table 4.4, especially the FStatistic $=13.38(\mathrm{P}-$ value $=0.046)$ and $33.14(\mathrm{P}-$ value $=0.000)$ the findings showed satisfactory evidence against the null hypotheses which are 'Debt capital has no significant effect on the profitability of firms in the downstream sub-sector of the oil and gas industry in Nigeria and Interest Rate has no significant effect on the relationship between Debt capital and profitability of firms in the downstream sub-sector of the oil and gas industry in Nigeria'. Thus, it was inferred that Debt capital has significant effect on the profitability of firms in the downstream sub-sector of the oil and gas industry in Nigeria and Interest Rate has significant effect on the relationship between Debt capital and profitability of firms in the downstream sub-sector of the oil and gas industry in Nigeria'.

Findings: One of the major findings from the empirical analysis is that Debt capital exerted a significant negative effect on profitability of the firm; that is, an increase in debt capital in the capital structure would result in decline in the profitability of the firms. The result of this analysis supports the findings of Tahmoorespur, Mina and Randjbaran (2015), Ogebe, Ogebe and Alewi (2013), Chechet and Olayiwola (2014), Osuji and Odita (2012) and Zeitun and Tang (2007). Tahmoorespour et al (2015) fiound that debt to capital of companies in the oil and gas industry shown a negative relationship with profitability. Ogebe, Ogebe and Alewi (2013) examined the impact of capital structure on firms' performance in Nigeria using annual panel data and regression estimation technique on data of firms listed on the Nigeria Stock Exchange. The study confirmed that there is a negative relationship between leverage (gearing) and firm's performance in selected companies in Nigeria. Similarly, Osuji and Odita (2012) studied the impact of Capital Structure on the financial performance of Nigerian firms using ordinary least squares model on panel data of thirty (30) listed non-financial firms in Nigeria between 2001 and 2007. The result showed that a firm's capital proxied by Debt Ratio has a significant negative impact on the firm's financial measures (Return on Asset and Return on Equity). The result of this analysis did not support the findings of Odalo, Achoki and Njuguna (2016). Odalo et al. (2016) carried out the study to establish the influence of interest rate on the financial performance of agricultural firms listed on the Nairobi Securities Exchange. The study combined primary and secondary data. According to the authors, the primary data were collected using questionnaire while the secondary data were collected using data collection sheets from the firms as well as from the Nairobi Securities Exchange and CMA records. From the study, the findings revealed that interest rate has a positive and significant relationship with ROA. 
Table 4.5: Return on Asset (ROA) and Equity Capital (EQUITCAP)

\begin{tabular}{|c|c|c|c|c|c|}
\hline VARIABLES & & $\frac{(1)}{\text { SGMM }}$ & $\frac{(2)}{\mathrm{DGMM}}$ & $\frac{(3)}{\text { SGMM1 }}$ & $\frac{(4)}{\mathrm{DGMM} 1}$ \\
\hline L.ROA & $\begin{array}{c}\text { Coef. } \\
\text { StdEr. } \\
\text { t-stat. } \\
\text { P - value }\end{array}$ & $\begin{array}{c}\mathbf{0 . 2 2 7 6} * * * \\
(0.0429) \\
5.3015 \\
(0.0007)\end{array}$ & $\begin{array}{c}\mathbf{0 . 1 4 7 4} \% \\
(0.0737) \\
1.9990 \\
(0.0806)\end{array}$ & $\begin{array}{c}\mathbf{0 . 2 1 7 7} * * * \\
(0.0480) \\
4.5372 \\
(0.0019)\end{array}$ & $\begin{array}{c}\text { 0.1496* } \\
(0.0689) \\
2.1722 \\
(0.0616)\end{array}$ \\
\hline EQUITCAP & $\begin{array}{c}\text { Coef. } \\
\text { StdEr. } \\
\text { t-stat. } \\
\text { P - value }\end{array}$ & $\begin{array}{c}\mathbf{0 . 0 4 1 7} * * \\
(0.0157) \\
2.6631 \\
(0.0287)\end{array}$ & $\begin{array}{c}\mathbf{0 . 1 4 0 0 * *} \\
(0.0561) \\
2.4967 \\
(0.0371)\end{array}$ & $\begin{array}{c}\mathbf{0 . 0 4 7 6 * * *} \\
(0.0110) \\
4.3321 \\
(0.0025)\end{array}$ & $\begin{array}{c}\mathbf{0 . 1 3 4 6} * * \\
(0.0556) \\
2.4199 \\
(0.0419)\end{array}$ \\
\hline INTR & $\begin{array}{c}\text { Coef. } \\
\text { StdEr. } \\
\text { t-stat. } \\
\text { P - value }\end{array}$ & $\begin{array}{c}\mathbf{- 0 . 1 5 1 6} \\
(2.0922) \\
-0.0725 \\
(0.9440)\end{array}$ & & $\begin{array}{c}\mathbf{0 . 8 7 1 9} \\
(0.5231) \\
1.6669 \\
(0.1341)\end{array}$ & $\begin{array}{c}\mathbf{0 . 6 5 2 9} \\
(0.3944) \\
1.6553 \\
(0.1364)\end{array}$ \\
\hline Constant & $\begin{array}{c}\text { Coef. } \\
\text { StdEr. } \\
\text { t-stat. } \\
\text { P - value }\end{array}$ & $\begin{array}{c}\mathbf{- 0 . 1 5 1 6} \\
(2.0922) \\
-0.0725 \\
(0.9440)\end{array}$ & & $\begin{array}{c}\mathbf{- 1 5 . 8 3 8 4} \\
(9.6183) \\
-1.6467 \\
(0.1382)\end{array}$ & \\
\hline $\begin{array}{l}\text { Observations } \\
\text { F-statistic } \\
\text { Prob.(F-Stat.) } \\
\text { Hansen_test } \\
\text { Prob. (Hansen) } \\
\text { AR(1)_test } \\
\text { Prob. (AR(1)) } \\
\text { AR(2)_test } \\
\text { Prob. (AR(2)) } \\
\text { No. of Instruments }\end{array}$ & & $\begin{array}{c}\mathbf{1 6 2} \\
15.90 \\
0.002 \\
7.661 \\
0.973 \\
-2.570^{* *} \\
0.010 \\
0.648 \\
0.517 \\
2\end{array}$ & $\begin{array}{c}\mathbf{1 5 3} \\
7.15 \\
0.017 \\
0.199 \\
0.655 \\
-1.406 \\
0.160 \\
0.393 \\
0.695 \\
3\end{array}$ & $\begin{array}{c}\mathbf{1 6 2} \\
31.61 \\
0.000 \\
7.513 \\
0.976 \\
-1.991^{* *} \\
0.046 \\
0.521 \\
0.602 \\
2\end{array}$ & $\begin{array}{c}\mathbf{1 5 3} \\
9.55 \\
0.005 \\
0.167 \\
0.683 \\
-1.412 \\
0.158 \\
0.296 \\
0.767 \\
4\end{array}$ \\
\hline
\end{tabular}

Source: Authors' computations (2020)

Robust standard errors in parentheses

$* * * \mathrm{p}<0.01, * * \mathrm{p}<0.05, * \mathrm{p}<0.1$

The empirical representation of the estimated SGMM model is as shown below;

$\mathrm{ROA}_{\mathrm{it}}=\alpha_{0}+\beta_{1} \mathrm{ROA}_{\mathrm{it}-1}+\beta_{2}$ EQUITCAP $_{\mathrm{it}}+\varepsilon_{\mathrm{it}}$

$\mathrm{ROA}_{\text {it }}=\mathbf{- \mathbf { 0 . 1 5 1 6 }}+\mathbf{0 . 2 2 7 6} * \mathrm{ROA}_{\mathrm{it}-1}+\mathbf{0 . 0 4 1 7} * \mathrm{EQUITCAP}_{\text {it }}+\varepsilon_{\mathrm{it}}$

$\mathrm{ROA}_{\mathrm{it}}=\alpha_{0}+\beta_{1} \mathrm{ROA}_{\mathrm{it}-1}+\beta_{2} \mathrm{EQUITCAP}_{\mathrm{it}}+\beta_{3} \mathrm{INTR}_{\mathrm{it}}+\varepsilon_{\mathrm{it}}$

Eqn. (3)

Eqn. (3)

$\mathrm{ROA}_{\mathrm{it}}=-15.838+0.2177 * \mathrm{ROA}_{\mathrm{it}-1}+0.048 * \mathrm{EQUITCAP}_{\mathrm{it}}+0.872 * \mathrm{INTR}_{\mathrm{it}}+\varepsilon_{\mathrm{it}}$

\section{Serial correlation test and over-identification restrictions}

To verify the behaviour of the error term as well as the instruments used in dynamic regression models that investigate the relationship between Equity Capital (EQUITCAP) and profitability of the selected firms (measured by Return on Asset (ROA)), serial correlation and over-identifying restrictions tests were carried out and the results are presented in Table 4.5. The result showed that the AR(1) statistics for the models that regressed Profitability indicator (Return on Asset) on its lag and Equity Capital (EQUICAP) in columns (1) and (2) are given as -2.570 $(\mathrm{p}-$ value $=0.010)$ and $-1.406(\mathrm{p}-$ value $=0.160)$ for the one-step system GMM (SGMM) and one-step difference GMM (DGMM) respectively. Also, the result showed that the AR(1) statistics for the models that regressed Profitability indicator (Return on Asset) on its lag, Equity Capital (EQUICAP) and Interest rate (INTR) in columns (3) and (4) of Table 4.5 are given as $-1.991(\mathrm{p}-$ value $=0.046)$ and $-1.412(\mathrm{p}-$ value $=0.158)$ for the one-step system GMM (SGMM1) and one-step difference GMM (DGMM2) respectively. These indicate that AR(1) of one-step system GMMs are statistically significant at 5\% level as expected. These, therefore, signal presence of serial correlation in the first order in the models. Conversely, the result further showed absence of serial correlation in the second order of the SGMMs model in columns (1) and (2) because the AR(2) statistic is given as 0.648 (p - value $=0.517)$ and $0.521(\mathrm{p}-$ value $=0.602)$. Additionally, the test for over-identifying restriction showed lack of correlation between instruments and the error term (valid instruments) because the Hansen statistics value of 
$7.661(\mathrm{p}-$ value $=0.973)$ and $7.513(\mathrm{p}-$ value $=0.976)$ for columns $(1)$ and $(2)$ respectively are not statistically significant at the $5 \%$ level.

\section{Return on Asset (ROA) and Equity Capital (EQUITCAP)}

The inference from the SGMM model, the results in column (1) of Table 4.5 shows a significant result ( $\mathrm{F}$ - statistic $=15.90 ; \mathrm{p}-$ value $=0.002)$ further suggested that the model is valid. In other words, Equity Capital (EQUICAP) and Return on Asset (ROA) at lag period 1 jointly explained variations in the current Return on Asset (ROA). Looking more closely at the results, past value of Return on Asset (ROA) exhibited positive and significant relationship with current value of ROA at $1 \%$ level of significance. Consequently, the positive and significant relationship indicated that previous ROA is a significant determinant of profitability indicator (ROA). It also meant that current ROA increases by 0.228 units given a unit increase in past ROA. Furthermore, the result shows that the current Equity Capital ratio has a positive and significant relationship with current ROA at $5 \%$ level. This suggested that the EQUICAP is a significant determinant of ROA and that a unit increase in EQUICAP leads to about 0.042 units decrease in ROA of the selected oil and gas firms.

\section{Return on Asset (ROA) and Equity Capital (DEBTCAP) as well as Interest Rate (INTR)}

As in the SGMM1 model result in column (3) of Table 4.5, the F- statistic $=31.61 ; \mathrm{p}$ - value $=0.000$ ) is significant, thus, further suggesting that the model is valid. In other words, the combined effect of equity capital (EQUITCAP), Interest Rate (INTR) and Return on Asset (ROA) at lag period 1 on current Return on Asset (ROA) is statistically significant. In addition, the result showed that past value of Return on Asset (ROA) exhibited positive and significant relationship with current value of ROA at $1 \%$ level of significance and this significant and positive and relationship indicated that previous ROA is a significant determinant of profitability indicator (ROA) just as in the previous model. It also meant that current ROA increases by 0.217 units given a unit increase in past ROA. In addition, the result showed that the current Equity Capital ratio (EQUITCAP) has a negative and significant relationship with current ROA at $1 \%$ level. The negative impact becomes stronger and more significant after Interest Rate (INTR) has been added as the moderating variable. This suggested that the EQUITCAP is a significant factor of changes in ROA and Interest rate in addition to it being an influence on the effect of EQUITCAP on ROA of the selected oil and gas firms. Furthermore, the result showed that the current Interest Rate has a positive and insignificant relationship with current ROA at $5 \%$ level. This is suggesting that INTR is not a significant determinant of ROA of the selected oil and gas firms during the period of this study, although, it influenced the impact of EQUITCAP on ROA.

Decisions: Based on the result of the regression analysis (1) and (3) of Table 4, especially the F- Statistic $=15.90$ $(\mathrm{p}-$ value $=0.002)$ and $31.61(\mathrm{p}-$ value $=0.000)$, there is substantial evidence against the null hypotheses which are that 'Equity capital has not significantly affected the profitability of firms in the downstream sub-sector of the oil and gas industry in Nigeria and Interest Rate has no significant effect on the relationship between equity capital and profitability of firms in the downstream sub-sector of the oil and gas industry in Nigeria'. Consequently, the conclusion is that Equity capital has significantly affected the profitability of firms in the downstream sub-sector of the oil and gas industry in Nigeria and Interest Rate has significant effect on the relationship between equity capital and profitability of firms in the downstream sub-sector of the oil and gas industry in Nigeria.

Findings: Another major finding from the empirical analysis is that Equity capital exerted a significant positive effect on profitability of the firms, that is, an increase in equity capital in the capital structure would result in increase in the profitability of the firms. The result of this analysis supports the findings of Jeleel and Olayiwola (2017). In the study, the authors assessed the relationship between leverage and Return on Assets of firms listed on the Nigerian Stock Exchange which belong to Chemicals and Paints firms using a sample of three firms and chosen from a total of nine firms listed in the sector for a period of ten years, $2000-2009$. Also, the estimation technique adopted for the data sourced secondarily from the NSE Fact-book (various issues) covering the period of the study of the selected firms was Ordinary Least Square (OLS). Return on Assets (ROA) was used as measure of performance while Equity (EQT) and Debt Ratio (DR) as proxies for capital structure in two different models. The authors found that EQT, the proxy for capital structure which is defined as a ratio of Equity to Total asset is positively and significantly related with ROA at 5\% level. According to the authors, the implication of the result is that any increase in the level of equity funding by entities in the Chemicals and Paints sector leads to a corresponding increase in ROA (firm performance) level.

\section{Conclusion and recommendations}

From the findings of the study, the study affirmed that debt capital ratio have a significant inverse effect on firms' profitability which suggested that the debt capital ratio is a significant factor in decreasing profitability of the selected oil and gas firms. Furthermore, Equity Capital ratio has a positive and significant effect on the profitability of the selected oil and gas firms. The result also affirmsed that Interest Rate has a positive and insignificant relationship with profitability of selected oil and gas firms during the period of this study. This confirmed that 
interest rate as a moderating factor in the model has no significant influence in the determination of the profitability of the firms studied.. The study, therefore, concluded that debt financing is not the best financing option for oil and gas firms in Nigeria. Additionally, the study also concluded that equity financing particularly retained earnings is the best financing option that will enhance the financial performance of firms in the oil and gas industry. In line with the findings, the study recommends the following:

i. That oil and gas companies intensify their efforts towards relying on internally generated funds to finance their operational activities. Even where external debt would be used, the companies should search for low interest-bearing loans so that the tax shield which is a form of subsidy in order to increase the profit after tax of the companies. This, in addition, will increase the rates of returns (both ROA and ROE), hence, shareholders' wealth.

ii. The oil and gas sector should adopt a policy that will encourage the use of equity financing, thereby reducing the high leverage ratio. Equity financing can be enhanced through increased retention of retained earnings without negatively affecting the amount of dividends paid to shareholders, ceteris paribus. .

iii. The government should create an enabling business friendly environment so that businesses can thrive through the use of both fiscal and monetary incentives especially the latter such as instituting macroeconomic objectives that can reduce interest rates.

\section{References}

Akinlo, O. \& Taiwo, A. (2012). Profitability and Leverage: Evidence from Nigeria Firms. Global Journal of Business Research, 6(1), 17-25.

Akinselure, P. (2017). Impact of capital structure on the profitability of selected quoted banks in Nigeria. International Journal of Economics, Commerce and Management, 5(1), 543-552.

Appah, E., Ekpe, O. \& Binaebi, B. (2013). Capital structure and the operating performance of quoted firms in the Nigeria Stock Exchange. Research Journal of Finance and Accounting, 4(5), 6-22.

Arellano, M. \& Bond, S. (1991). Some tests of specification for panel data: Monte Carlo evidence and an application to employment. The review of economic studies, 58(2), 277-297.

Bond, (2002). Dynamic panel data models: a guide to micro data methods and practice. Portuguese economic journal, 1(2), 141-162.

Blundell, R. \& Bond, S. (1998). Initial conditions and moment restrictions in dynamic panel data models. Journal of econometric, 87(1), 115-143.

CBN News 2015, The State of the Nigeria Economy During the Half of 2015. Lagos: Central Bank of Nigeria, Lagos.

Edim, N. O., Atseye, F. A. \& Eke, F. A. (2014). Relationship between Capital Structure and Firm's Performance; Theoretical Review. Journal of Economics and Sustainable Development, 5(17),201.

Gujarati, D.N. (2003). Basic Econometrics, Forth Edition, New Delhi, Tata Mc-Graw-Hill Publishing Company Limited.

Hsiao, C. (2005). Why Panel data?. The Singapore economic review , 50(2), 143-154.

Hsiao, C. (2007). Panel data analysis-advantages and challenges. Test 16(1), 1-22.

Chechet. I.L. \& Olayiwola, A.B. (2014). Capital Structure and Profitability of Nigeria Quoted Firms; the Agency Cost Perspective. American International Journal of Social Science, 3(1), 139-158.

Jeleel, A. \& Olayiwola, B. (2017). Effect of Leverage on firm performance in Nigeria: A case of Listed Chemicals and paints firms in Nigeria. Global journal of management and business research, 17(2), 3-11.

Modigliani, F. \& Miller, M.H. (1958). The Cost of Capital, Corporation of Finance and the Theory of Investment. The American Economic Review 48(3). 261-297.

Green, S. (2004). The development of China's stockmarket, 1984-2002: equity politics and market institutions. Routledge.

Nwankwo, O. (2014). Effect of Capital Structure of Nigerian Firms on Economic Growth. Mediterranean Journal of Social Sciences, 5(1), 515-519.

Odalo, S. K., Achoki G. \& Njuguna A. (2016). Influence of Interest Rate on the Financial Performance of Agricultural Firms Listed at the Nairobi Securities Exchange. American Journal of Finance, 1 (3), 19 - 34.

Ogebe P., Ogebe, J. \& Alewi, K. (2013). The impact of Capital Structure on Firms' Performance in Nigeria. St Augustine College of Education Lagos. Available online at http://mpra.ub.uni-muenchen.de/46173.

Olokoyo, F.O. (2012) Capital Structure and Corporate Performance of Nigeria Quoted Firms. A Panel Data Approach. Africa Development Review, 25(3), 358-369.

Osuji, C.C. \& Odita, A. (2012). Impact of Capital Structure on the Financial Performance of Nigerian Firms. Arabian Journal of Business and Management Review, 1(12). 43.

Pandey, I.M. (2010). Financial Management, Vikas Publishing House PVT. Ltd. Delhi.

Pandey, I. M., 2006. Financial management (pp: 1225). New Dethi: Vikas Publishing Company Ltd. 
Pratomo, W., \& Ismail, A. (2006). Islamic bank performance and capital structure. Journal of Finance, 22(5), 1018.

Rahman, A., Sarker, I., \& Uddin, J. (2019). The impact of capital structure on the profitability of publicly traded manufacturing firms in Bangladesh. Journal of Applied Economics and Finance, 6(2), 1-5.

Revia, A. (2014). Business environment and stock market development: an empirical analysis. A presentation at the doing business research conference: past, present and future of business regulation, February 2014.

Richard Blundell and Stephen Bond. Initial conditions and moment restrictions in dynamic panel data models. $87(1), 115-143$.

Salawu, R. O. \& Awolowo, O. (2009). The effect of Capital Structure on Profitability: An empirical analysis of listed firms in Nigeria. The International Journal on Business and Finance Research, 3(2). 121-129.

Tahmoorespur, R., Mina, A. \& Randjbaran, E. (2015). The impact of capital structure on stock returns: international evidence. Hyperion Economic Journal, 1(3), 56-78.

Yaffee, R. (2003). A primer for panel data analysis. Connect: information technology at NYU, 1-11.

Yartey, C.A. (2008). Financial development, the structure of capital markets, and the global digital divide. Information economics and policy, 20(2), 2018-227.

Yegon, C. (2014). The effects of capital structure on profitability of Kenya's banking sector. Journal of Finance and Accounting, 5(9), 152-159.

Yisau, L. (2016). Analysis of capital structure and effectiveness of business enterprises for national sustainable development and disaster management. Journal of Emerging Trends in Educational Research and Policy Studies, 7(4), 318-325.

Zeitun, R. and Tian, G.G, (2007). Capital Structure and Corporate Performance: Evidence from Jordan. Australia Accounting, Business and Finance Journal. 1(4), 148-168.

Appendix: Stratified Population of Companies

\begin{tabular}{|l|l|}
\hline Petroleum and Petroleum Product Distribution Company & Integrated Oil and Gas Company. \\
\hline Total Oil Plc & OandoPlc \\
\hline Mobil Oil Plc & \\
\hline Forte Oil Plc & \\
\hline Japaul Oil \& Maritime Services Plc & \\
\hline MRS Oil Nigeria & \\
\hline Eterna Oil & \\
\hline Rak Unity Pet. Com. Plc & \\
\hline Capital Oil Plc & \\
\hline
\end{tabular}

Source: Nigerian Stock Exchange (2018) 